\title{
西藏米林Ms6.9级地震余震定位和地壳浅层速度结构
}

叶进 ${ }^{1,2}$, 赵俊猛 ${ }^{1}$, 刘红兵 ${ }^{1^{*}}$, 张衡 ${ }^{1}$, 徐强 ${ }^{1}$, 陈树泽 ${ }^{1,2}$

1. 中国科学院青藏高原研究所, 中国科学院大陆碰撞与高原隆升实验室, 北京 100101;

2. 中国科学院大学, 北京 100049

* 联系人, E-mail: hbliu@itpcas.ac.cn

2019-09-29 收稿, 2020-02-13 修回, 2020-02-14 接受, 2020-05-13 网络版发表

国家重点研发计划(2016YFC0600301)、中国科学院A类战略性先导科技专项(XDA20070302)、国家自然科学基金(41776201, 41974109)、中国 科学院设备研制项目(YJKYYQ20190075)和中国科学院青年创新促进会(2018097)资助

摘要 北京时间2017年11月18日06时34分, 西藏自治区林芝市米林县发生了Ms6.9级地震. 为监测余震活动, 震后 围绕震中架设了28套宽频带地震台站获取了 $180 \mathrm{~d}$ 观测数据. 利用hypoDD双差地震定位法和LOTOS-12算法对余震 事件进行精定位. 结果表明, 余震以主震为中心NW-SE向展布长约 $50 \mathrm{~km}$ 、宽约 $30 \mathrm{~km}$, 根据余震分布推测存在3条 与西兴拉断裂走向基本一致的, 倾角自西北端向东南端逐渐变陡的活动断裂. 结合LOTOS-12算法同时获得地壳浅 层约 $20 \mathrm{~km}$ 深度以上的P波和 $\mathrm{S}$ 波速度扰动分布结果. 主震处于波速高低异常转换带, 余震主要发生在地震波P波和 $\mathrm{S}$ 波速度负异常区, 反映震源区地层破碎、断裂分布集中的特点. 整体上, 以南迦巴瓦峰为界, $\mathrm{P}$ 波和 $\mathrm{S}$ 波大致呈北部 高速异常, 南部低速异常特点. 该现象可能与北侧拉萨地体相对完整且岩性古老刚冷, 而南侧及南迦巴瓦变质体相 对破碎且岩石生成年代较新岩性软热有关. 此外, 紧邻南迦巴瓦峰西北侧区域的体波高速异常现象可能与该区域 石榴子石矿物富集有关。

关键词米林地震, 喜马拉雅东构造结, 地震定位, 发震构造, 速度结构

据中国地震台网中心(CENC)测定，北京时间2017 年11月18日06时34分(GMT: 2017-11-17 22:34), 西藏自 治区林芝市米林县发生 $M \mathrm{~s} 6.9$ 级强烈地震( 以下简称米 林地震), 是继1950年察隅 $M \mathrm{~s} 8.6$ 级大地震之后, 喜马拉 雅东构造结地区发生的最强烈地震. 中国地震台网中 心测定震源位置: $29.75^{\circ} \mathrm{N}, 95.024^{\circ} \mathrm{E}$, 震源深度 $10 \mathrm{~km}$. 中国科学院青藏高原研究所白玲等人 ${ }^{[1]}$ 利用近台和远 台数据对震源重定位: $29.87^{\circ} \pm 0.01^{\circ} \mathrm{N}, 95.02^{\circ} \pm 0.01^{\circ} \mathrm{E}$, 震源深度 $10 \mathrm{~km} \pm 2 \mathrm{~km}$. 中国地震局地质研究所韦伟等 人 ${ }^{[2]}$ 重定位结果: $29.87^{\circ} \mathrm{N}, 95.05^{\circ} \mathrm{E}$, 震源深度 $12 \mathrm{~km}$. 震 中处于地壳最大剪应变率的高梯度带上 ${ }^{[3]}$. 中国地震局 烈度图显示米林地震最大烈度为 VIII度, 面积约 $310 \mathrm{~km}^{2}$. 震中西南和正南方向䇯立两座海拔超7000 m的山峰
(图 1), 分别是加拉白垒峰 (7294 m) 和南迦巴瓦峰 (7782 m), 雅鲁藏布江在两座山峰间自西向东穿过, 冰 川河谷地貌发育, 地表侵蚀严重, 震后还未发现明显的 地表破裂带. 甘卫军等人震后得出的GPS同震位移场 (http://www.eq-igl.ac.cn/contents/43/29092.html)和刘云 华等人 ${ }^{[6]}$ 得出的InSAR 同震形变场数据结果显示: 发震 断层NE盘上升而SW盘下沉, 同时断层两侧滑动位移指 向震中, 推测主震属于逆冲型地震. 根据发震断层面走 向 NW、倾向NE的特点 ${ }^{[3,6]}$, 推测主震震源机制解 ${ }^{[1]}$ 倾 角较高的节面属于真实发震断层面, 认为发震断层以 逆冲挤压为主兼具右旋走滑特征 ${ }^{[2,6]}$.

米林地震震中位于南迦巴瓦复式背斜东北边缘, 西兴拉断裂带 $(\mathrm{XXL})$ 西南侧, 周边还发育了嘉黎断裂 


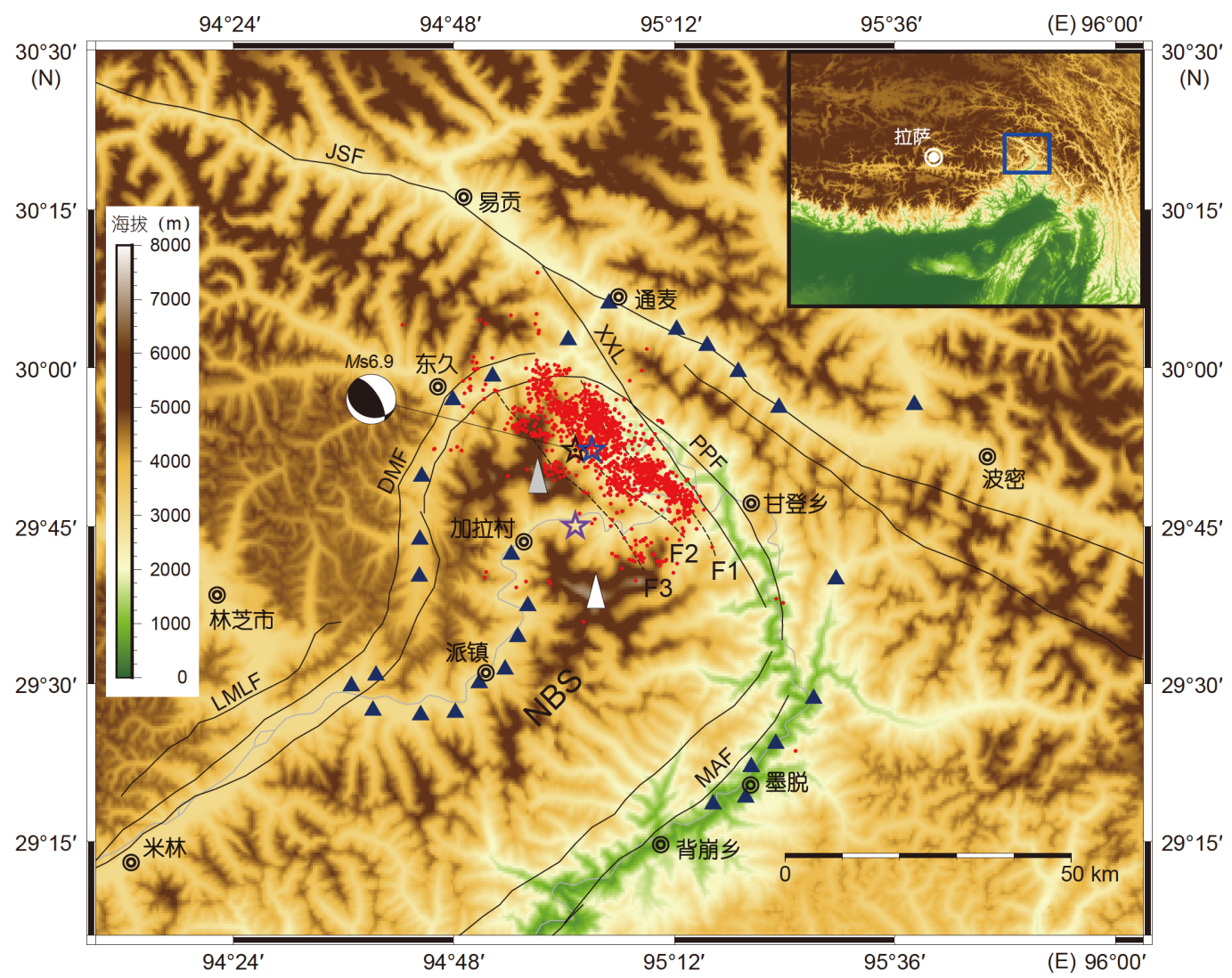

图 1 米林地震震中余震及周边主要断裂分布图. 黑色实线为断裂分布示意: DMF, 东久-米林断裂; XXL, 西兴拉断裂; JSF, 嘉黎断裂; MAF, 墨 脱-阿尼桥断裂; PPF, 迫龙-旁辛断裂; LMLF, 喇啉岭断裂; NBS, 南迦巴瓦构造结. 黑色虚线为根据余震分布推测的 3 条主要断裂位置示意, 红色 圆点代表余震事件, 蓝色三角为观测台站. 灰色三角为加拉白垒峰, 白色三角为南迦巴瓦峰. 黑白沙滩球代表主震震源机制解 ${ }^{[1]}$. 紫色、黑色和 蓝色三角形分别代表CENC、白玲等人 ${ }^{[1]}$ 和韦伟等人 ${ }^{[2]}$ 的米林主震定位结果. 右上角插图中蓝色方框代表研究区域. 断裂分布引自Ding等人 ${ }^{[4]}$ 和 邓起东等人 ${ }^{[5]}$

Figure 1 Distribution of aftershocks and major faults surrounding the epicenter of the Mainling earthquake. The black solid line is the fault distribution: DMF, Dongjiu-Mainling fault; XXL, Xixingla fault; JSF, Jiali fault; MAF, Motuo-Aniqiao fault; PPF, Polong-Pangxin fault; LMLF, Lamaling fault; NBS, Namche Barwa syntaxis. The black dotted line is the three main fault locations estimated based on the aftershock distribution, the red dot represents the aftershock event, the blue triangle is the observation station, the gray triangle is the Galabaire Peak, and the white triangle is the Namcha Barwa Peak. Black and white beach ball represents the focal mechanism solution of the main shock ${ }^{[1]}$. The purple, black, and blue triangles represent the results of Milin main shock location from CENC, Bai et al. ${ }^{[1]}$, and Wei et al. ${ }^{[2]}$. The blue box in the upper right illustration represents the study area. The faults distribution are derived from Ding et al. ${ }^{[4]}$ and Deng et al. ${ }^{[5]}$

(JSF)等一系列大型走滑断裂(图1)，地表破碎、地质构 造复杂、地震活动频繁, 且多为浅源地震 ${ }^{[7]}$. 前人计算 了米林地震对周边断层的同震库伦应力, 认为米林地 震对震源区附近的活动断层产生了一定影响, 对较远 处的断层影响较小 ${ }^{[8]}$. 其中紧邻震源区东北侧的XXL 作为连接JSF和南迦巴瓦构造结(NBS)的重要断裂带, 走向分布和形态特点研究受当地自然环境条件所限, 可供参考地震资料不多, 研究程度较低.

地震发生后，第二次青藏高原综合科学考察队立 即组织了林芝地震应急科考分队，到达地震核心区开 展地震地质灾害调查与地震对环境影响分析. 同时, 为
观测震后余震活动分布，中国科学院青藏高原研究所 围绕震中区域紧急布设28套流动地震台站组成米林台 网(图1)，对余震连续观测 $180 \mathrm{~d}$ 左右，平均台间距约 $5 \mathrm{~km}$, 对震源区实现了良好覆盖, 较大丰富了喜马拉雅 东构造结地震数据资料. 运用hypoDD双差地震定位法 和LOTOS-12地震定位与速度结构联合反演算法对米 林地震众多余震事件进行精定位，探讨XXL及周边区 域断裂分布与活动性，同时对震中及附近区域的体波 速度结构进行反演. 相比前人对青藏高原东南部大尺 度速度结构成像，对南迦巴瓦构造结及周边断裂带地 壳浅层精细速度结构的研究, 更有助于详细认识印度 
板块与拉萨地体碰撞俯冲前缘区域的地质地球物理 特征.

\section{1 数据和方法}

米林台网所用地震计包括14个CMG-3ESP宽频带 地震计、4个STS-2甚宽频带地震计和 10 个BBVS-60甚 宽频带地震计, 所用数据采集器为REFTEC-130, 除一 套仪器因故障仅记录数据一周左右, 其余台站均工作 正常. 自2017年11月25日布设完成到2018年5月25日台 站回收, 共连续记录地震数据 $180 \mathrm{~d}$ 左右. 震相拾取过程 中, 采用手动拾取方法结合PhasePapy半自动拾取软件 进行，设置倍频程滤波器的初始滤波中心频率为 $1 \mathrm{~Hz}$, 之后结合实际波形动态调整滤波频段. 为保证震相到 时数据拾取的质量, 在震相拾取过程中除了剔除异常 波形，对每个地震事件要求至少被4个台站记录，而且 每个地震事件至少有 8 条震相信息被台站所记录, 为保 证更精准的地震定位结果, 并且避免因为 $\mathrm{P}$ 波与 $\mathrm{S}$ 波数 据量不同，而出现一方权重过大影响波速比 $(V \mathrm{p} / V \mathrm{~s})$ 计 算准确性, 要求每个分量中的 $\mathrm{Pg}$ 和 $\mathrm{Sg}$ 波震相均包含在 内. 最终米林台网经篮选共拾取 $\mathrm{Pg} 、 \mathrm{Sg}$ 波震相到时数 据37762条(图2), 平均拾取误差0.097 s, 共记录地震事 件(主震震中 $\pm 0.6^{\circ}$ ) 3036 个. 中国台网正式地震目录由 于观测台站稀疏，记录的余震数目只有 541 个，其中震 级 $\geqslant 1.0$ 的有 347 个, 米林台网较好完善了米林地震后余 震目录信息.

本研究基于米林台网记录的 $\mathrm{P} 、 \mathrm{~S}$ 波震相到时数 据, 先采用hypoDD双差地震定位法对余震初步定位, 再利用LOTOS-12(local tomography software)地震定位 与速度结构联合反演算法对余震事件进行精定位，同 时获得该地区地壳浅层速度结构. 其中, hypoDD双差 地震定位法采用了波形互相关技术，用两个地震的实 际观测走时与理论走时的最小残差实现定位 ${ }^{[9]}$, 在国 内具有广泛应用, 适合区域地震研究. LOTOS系列算 法自Koulakov等人 ${ }^{[10]} 2006$ 年提出后, 经过不断改进已 更新到LOTOS-12版本，比较适用于具有显著物态性质 差异地区的速度结构反演. 该算法根据研究区地震射 线密度分布情况, 在不同深度水平面上, 按一定初始方 位布设参数化网格节点, 在节点处建立并求解目标函 数 ${ }^{[11]}$, 同时根据射线弯曲追踪原理, 对布设的参数化节 点的自由参数进行反演计算，从而获取该节点处的速 度信息. 而在节点与节点之间的速度采取线性近似处 理 $^{[11]}$, 但是为了减少节点最初布设的方位对最终反演

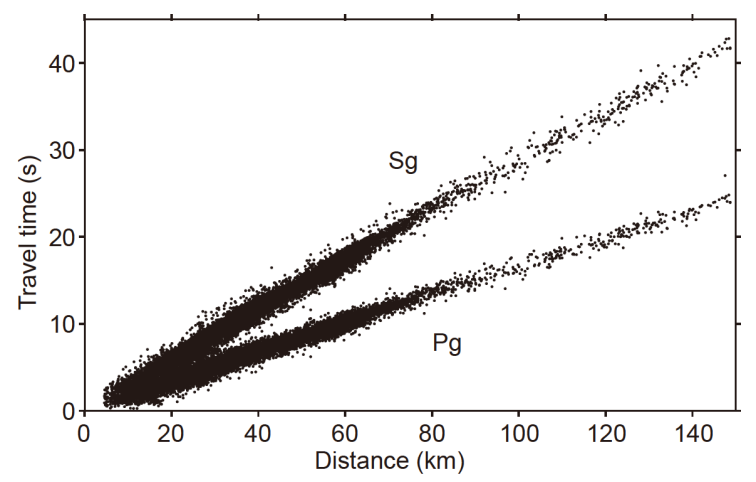

图 2 篮选后的 $\mathrm{Pg}$ 波和 $\mathrm{Sg}$ 波走时曲线

Figure 2 The travel-time curve of $\mathrm{Pg}$ wave and $\mathrm{Sg}$ wave after selected

结果的影响, 需要通过水平旋转变换节点初始布设方 位，经过对不同布设方位节点的计算结果进行叠加来 获取该空间区域的地震波速度结构. 最后经过5次迭代 反演后获取的目标函数极值确定余震震源位置, 同时 获取了 $\mathrm{P}$ 波和 $\mathrm{S}$ 波速度结构 $(V \mathrm{p} 、 V \mathrm{~s})$, 并计算得出相应 区域 $\mathrm{P} 、 \mathrm{~S}$ 波速度的比值分布 $(V \mathrm{p} / V \mathrm{~s}, \mathrm{http}: / / \mathrm{www}$.ivanart.com/science/LOTOS/index.html).

\section{2 余震分布}

余震事件的精确定位，可以为深人了解断层破裂 范围, 清楚认识研究区内断层深部的分布形态与活动 性质提供重要参考, 进而为今后防灾减灾提供可靠建 议. 由于研究区缺少可靠的初始速度模型, 本次地震定 位参照了白玲等人 ${ }^{[1]}$ 根据Crust 1.0 模型简化处理过的一 维速度模型：地表以下 $0 \sim 22 \mathrm{~km}$ (上地壳): $V \mathrm{~s}-3.5 \mathrm{~km} / \mathrm{s}$, $V \mathrm{p}-6.0 \mathrm{~km} / \mathrm{s} ; 22 \sim 44 \mathrm{~km}$ (中地壳): $V \mathrm{~s}-3.7 \mathrm{~km} / \mathrm{s}, V \mathrm{p}-6.4$ $\mathrm{km} / \mathrm{s} ; 44 \mathrm{~km}$ 以下(下地壳): $V \mathrm{~s}-3.9 \mathrm{~km} / \mathrm{s}, V \mathrm{p}-7.1 \mathrm{~km} / \mathrm{s}$. 经 hypoDD双差法地震事件组对后篮选获取初步定位的 地震事件 2451 个, P、S 波平均走时残差均方根(RMS) 为 $0.291 \mathrm{~s}$. 之后, 将初步定位结果输人LOTOS-12算法 对余震位置和研究区速度结构同时进行反演, 经过 5 次 迭代, 平均RMS值为 $0.071 \mathrm{~s}$, 残差缩小明显.

定位结果显示余震主要以主震为中心, 沿NW-SE 向展布在一个长约 $50 \mathrm{~km}$ 、宽约 $30 \mathrm{~km}$ 的狭小区域. 根 据余震在地表的投影, 发现余震大致沿与XXL断裂带 走向相同的方向呈带状分布(图1), 推测震中区域可能 发育有 3 条(F1、F2、F3)活动断裂. 其中, F1和F2相距 2 3 km, F2和F3相距3 4 km, 且断裂带走向并非平直, 具有“S”形弯曲变形特征, 米林地震主震发生在F2附近. 余震在主震东北侧数量较多且分布集中，而在主震西 
南侧数量较少且分布分散. 为研究断裂内部形态, 如图 $\mathrm{S} 1$ 所示, 沿蓝长线位置切割6个剖面, 将垂直剖面且距 剖面 $5 \mathrm{~km}$ 范围内的余震事件投影到各个剖面上. 通过 1-1'剖面发现余震主要分布在主震所处深度及以上区 域, 具有西北部震源深度较浅, 东南部相对西北部震源 深度加深的特点(图S1(b)).

为更清楚观察余震随时间序列分布状况，对 3 条断 裂带在深部的活动形态做更好限定，分别统计自 2017 年11月25日布台完毕开始记录的前 10、30、60和前 $100 \mathrm{~d}$ 共 4 个时间段内, 垂直投影到各个剖面上的余震事 件分布(图S2). 发现前 $30 \mathrm{~d}$ 余震活动频繁, $100 \mathrm{~d}$ 后余震 发生频率减弱. 统计期间, 余震在F1、F2和F3所在位置 集中分布的趋势逐渐明显. 其中 F1附近的余震数量相 对F2附近明显更多, 推测F1比F2活动更强烈; F3 余震 数量少且分布 $\left(2-2^{\prime} 、 3-3^{\prime} 、 6-6^{\prime}\right)$ 更加散乱, 推测其活 动性相对F1和F2较低. 结合 $3-3^{\prime} 、 4-4^{\prime}$ 和5-5'剖面的 余震事件分布, 认为 3 条断裂 $F 1 、 F 2$ 和 $F 3$ 的深部结构具 有显著NE向陡倾特征，与主震震源机制解节面的高倾 角特点 ${ }^{[2,6]}$ 相一致. 不同位置断层面倾角和下切深度略 有差异: 横向对比图S2中剖面2-2'至6-6', 发现蓝色短 线的倾角逐渐加大, 即F1、F2和F3的倾角自西北到东 南方向有逐渐变陡趋势 $\left(65^{\circ} \sim 85^{\circ}\right)$, 而下切深度自西北 向东南有逐渐加深趋势 $(11 \sim 15 \mathrm{~km})$, 与 $1-1^{\prime}$ 震源深度分 布特点相符合.

\section{3 速度成像}

分析成像结果之前，必须对反演结果的分辨率进 行检测，从而评估通过LOTOS-12算法获得的该地区地 壳浅层速度结构的分辨尺度. 本次研究采用检测板实 验(checkerboard test)对地表以下5、10、15和20 km深 度的速度结构成像结果进行分辨率测试. 设置 $5 \mathrm{~km} \times 5$ $\mathrm{km} \times 4 \mathrm{~km} 、 6 \mathrm{~km} \times 6 \mathrm{~km} \times 4 \mathrm{~km}$ 和 $7 \mathrm{~km} \times 7 \mathrm{~km} \times 4 \mathrm{~km}$ 三种检 测板网格尺度, 速度异常扰动范围设定 $\pm 5 \%$. 为了减小 参数化节点方向对反演结果带来的影响, 共预设 $0^{\circ}$ 、 $23^{\circ} 、 45^{\circ}$ 和 $68^{\circ}$ 四个方向对节点进行参数化, 并叠加获 取最终结果. 在 $10 \mathrm{~km}$ 深度范围内, 检测板网格大小 7 $\mathrm{km} \times 7 \mathrm{~km} \times 4 \mathrm{~km}$ 情况下(图S3), 震中及附近大部分区域 速度异常可以较好恢复; 网格大小 $6 \mathrm{~km} \times 6 \mathrm{~km} \times 4 \mathrm{~km}$ 情 况下, 中部和北部、东部和西部分辨率较好, 南部分辨 率较差; 而网格大小 $5 \mathrm{~km} \times 5 \mathrm{~km} \times 4 \mathrm{~km}$ 时, 只有中北部即 余震分布密集区域的分辨率比较好; 在 $10 \mathrm{~km}$ 以下深度, 分辨率较好区域主要集中在地震分布密集区，这是因
为基于射线弯曲追踪原理的LOTOS- 12 速度结构成像 算法的分辨率大小对射线密度比较敏感，而震源区地 震数目多、台站布设较密(图1), 该区域射线覆盖密度 更高, 从而分辨率相对更好 ${ }^{[12]}$, 对于东南地区由于地震 数目和台站数量低于中北部区域(图1), 导致射线分布 密度相对较低, 成像结果分辨率不如中北部区域.

根据震中及周边区域地震波速度扰动反演结果 (图3), 发现研究区浅层地壳速度结构比较复杂, 尤其是 主、余震分布区域处于地震波速度正负异常剧烈变化 区. 其中两条次级断裂带F1和F2所处的位置P波和S波 速度负异常，而F3处于 $\mathrm{P} 、 \mathrm{~S}$ 波速度负异常和西南侧正 异常过渡带. 根据地震波体波速度结构环境, 难以推测 F3与另外两条断裂同属于一组次级断裂带. 而南迦巴 瓦峰也处于P波、S波速度正负异常过渡地带: 整体来 看，在 $20 \mathrm{~km}$ 深度范围内，过南迦巴瓦峰有一条走向东 西向的“界线”，在“界线”北侧(主、余震分布区除外)大 部分区域P波速度呈正异常特点，东南侧P波速度呈负 异常特点. 根据 $\mathrm{S}$ 波波速异常情况，发现在5、10、 15、20 km深度, 南迦巴瓦变质体北侧和东侧大范围内 $\mathrm{S}$ 波速度正异常, 而西部和西南侧 $\mathrm{S}$ 波速度相对偏低, 甚 至出现负异常. 随着地壳深度加深, $\mathrm{P}$ 波和S波波速在北 侧的正异常特征均出现削弱现象. 紧邻南迦巴瓦峰西 北侧有一直径约20 25 km区域, 其P波速度明显正异 常，该区域P、S波速比明显偏大，局部达到1.85, 并且 随深度加深, 波速比偏大区域有扩大趋势. 这些地震波 速度异常现象，可能与该区域地壳浅层地质结构和岩 石特性有关, 将在下节讨论中具体探讨.

为了更直观认识研究区体波速度结构分布在深度 上的变化, 以图3中P波速度异常图观测到的紧邻南迦 巴瓦峰西北侧 $\mathrm{P}$ 波高异常区域为中心, 分别以自西向东 $\left(1-1^{\prime}\right)$ 和自北向南 $\left(2-2^{\prime}\right)$ 两个方向做切割剖面, 剖面具 体位置如图3中P波和S波 $20 \mathrm{~km}$ 深度速度异常图中的两 条黑色直线所示. 剖面穿过了地震射线覆盖良好区域, 可以较准确呈现研究区地壳浅层速度结构特点. 两条 剖面上的P、S 波速度结构如图4所示: 米林地震主震发 震位置位于地震体波高低速异常变化剧烈区域, 其中 图4(a), (b)右侧均显示地震波低速异常现象, 该区域处 于XXL、PPF和MAF等主要断裂交汇区，雅鲁藏布江 流向在该区域发生自 SW-NE到NE-SW向的 $180^{\circ}$ 剧烈转 变(图1), 峡谷深切, 地势落差大(图4(a)). 图4(c)左侧垂 向有部分区域P波速度偏低, 米林地震多数余震事件集 中发生在该区域，次级断裂F1、F2和F3以及DMF、 


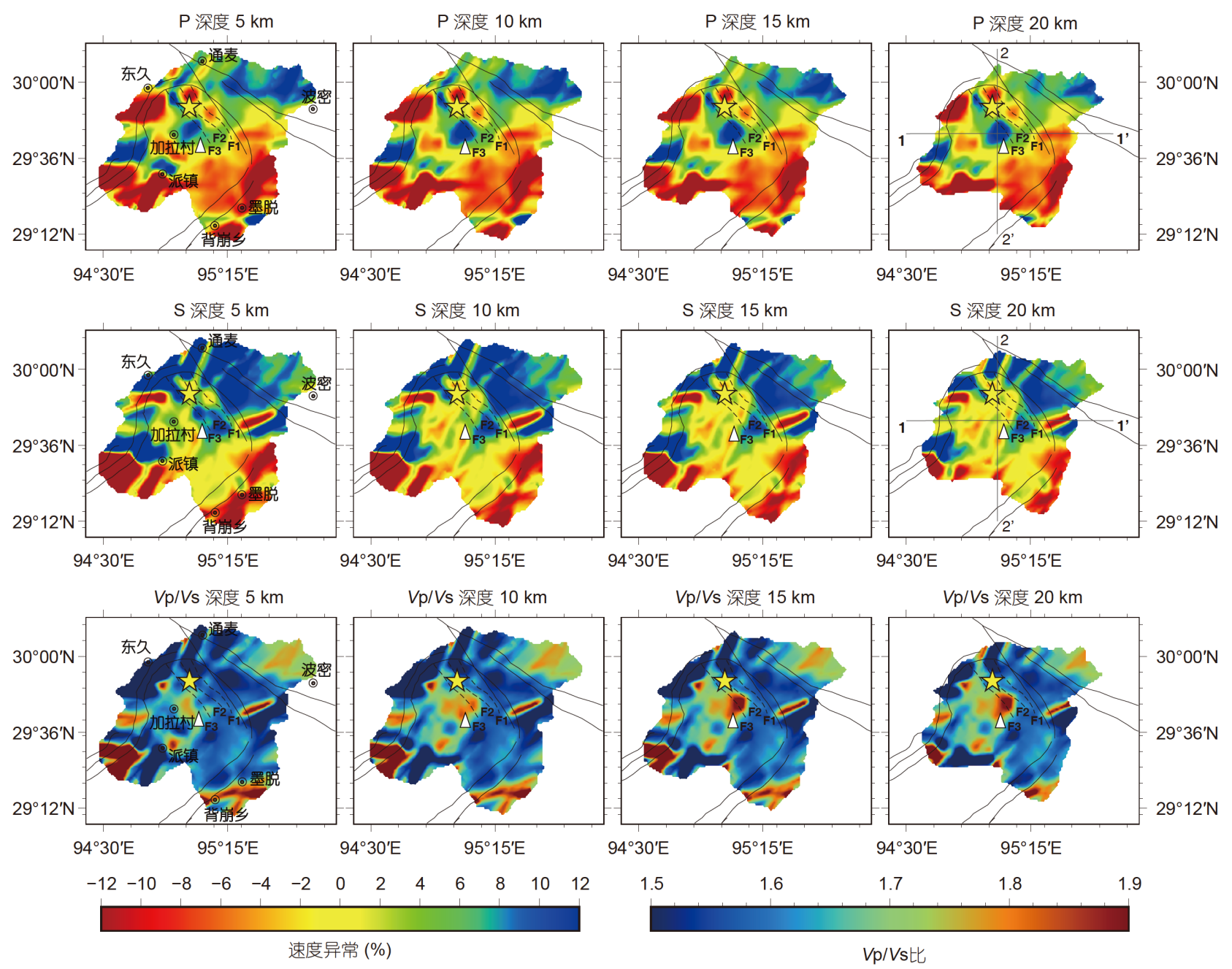

图 3 不同深度P波、S波速度扰动和波速比 $(V \mathrm{p} / V \mathrm{~S})$. 黄色五角星代表震中位置, 白色三角形代表南迦巴瓦峰位置; 黑色实线代表研究区主要断 裂, 黑色虚线代表推测的 3 条次级断裂; F1、F2和F3标示震中区 3 条次级断裂. P波、S 波速度 $20 \mathrm{~km}$ 深度扰动图上的黑色直线表示图4剖面1-1'和 $2-2$ '位置

Figure 3 P-wave and S-wave velocity perturbation and wave velocity ratio $(V \mathrm{p} / \mathrm{VS})$ at different depths. The yellow star represents the epicenter position of Mainling earthquake, the white triangle represents the position of the Namche Barwa Peak; the black solid line represents the main faults in the study area, and the black dotted line represents the speculated three secondary faults; F1, F2 and F3 mark three secondary faults in the epicenter. Black straight lines in the depth of $20 \mathrm{~km}$ of the P-wave and S-wave velocity perturbation indicate the positions of profile $1-1^{\prime}$ and $2-2^{\prime}$ in Figure 4

XXL和PPF等大型断裂(图1)在此交汇．两个剖面的P波 速度在中间区域(图4(a)，(c)中黑色虚线)相对周边有明 显偏高现象, 并且随深度加深, 异常区有横向加宽、并 向深部曼延的趋势.

\section{4 讨论}

此次地震震中位于喜马拉雅东构造结NE向碰撞俯 冲的前沿, 南迦巴瓦变质体东北缘(图1), 处于地壳发生 持续强烈构造变形的区域. 在受到印度大陆碰撞挤压 后，拉萨地体环绕南迦巴瓦变质体发生顺时针强烈偏 转 ${ }^{[13]}$, 导致在碰撞的前缘以挤压缩短-逆冲变形为主,
侧向以走滑变形为主, 在南迦巴瓦变质体东北侧, 由于 印支地块的挤出, 形成一系列NW-SE向走滑断裂 ${ }^{[14]}$. 其 中XXL北段中小地震频发, 但震源深度一般较浅.

根据余震定位结果，推测震中区域可能发育了 3 条 走向NW-SE、倾向NE的高倾角活动断裂，该组断裂活 动频繁, 触发了主震和以主震为中心, NW-SE向展布的 一系列余震. 3 条断裂断层面倾角自西北端到东南端具 有变大趋势(图S2), 与许志琴等人 ${ }^{[15]}$ 关于南迦巴瓦变质 体向北倾伏和向东南陡倾在拉萨地体之下的研究结论 耦合. 米林地震震中位于XXL断裂带西南侧约 $20 \mathrm{~km}$ 处, 结合前人对主震震源机制解和发震断层滑动分布研究 
Profile 1
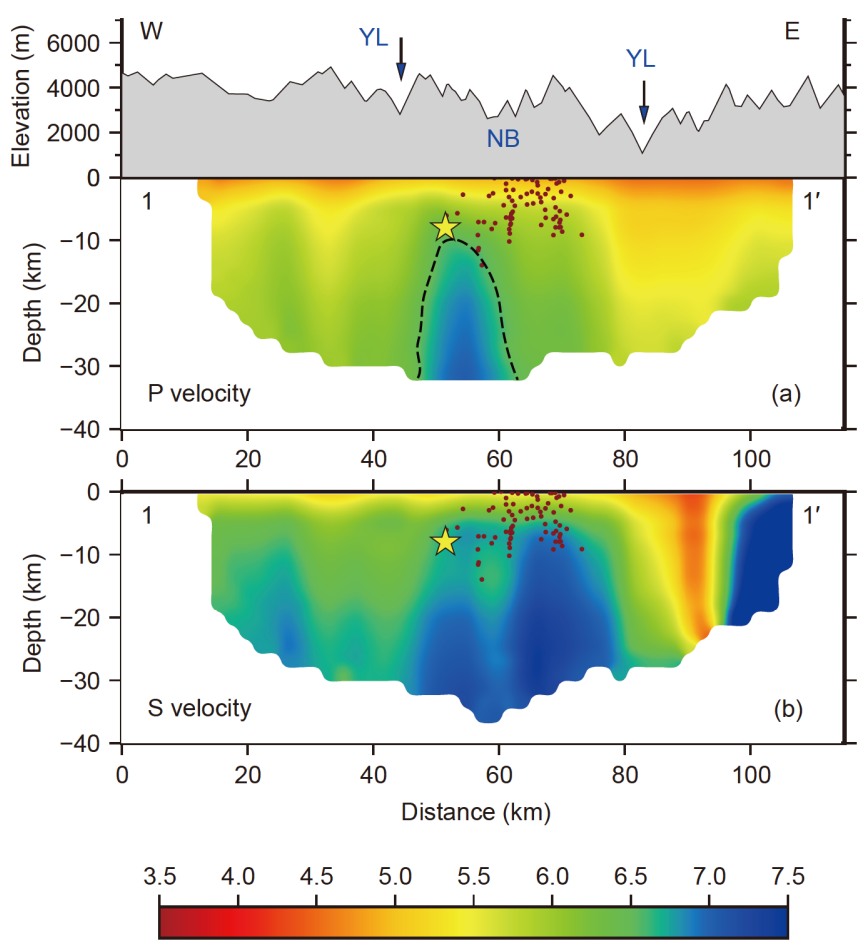

$\mathrm{P}$ absolute velocity $(\mathrm{km} / \mathrm{s})$
Profile 2

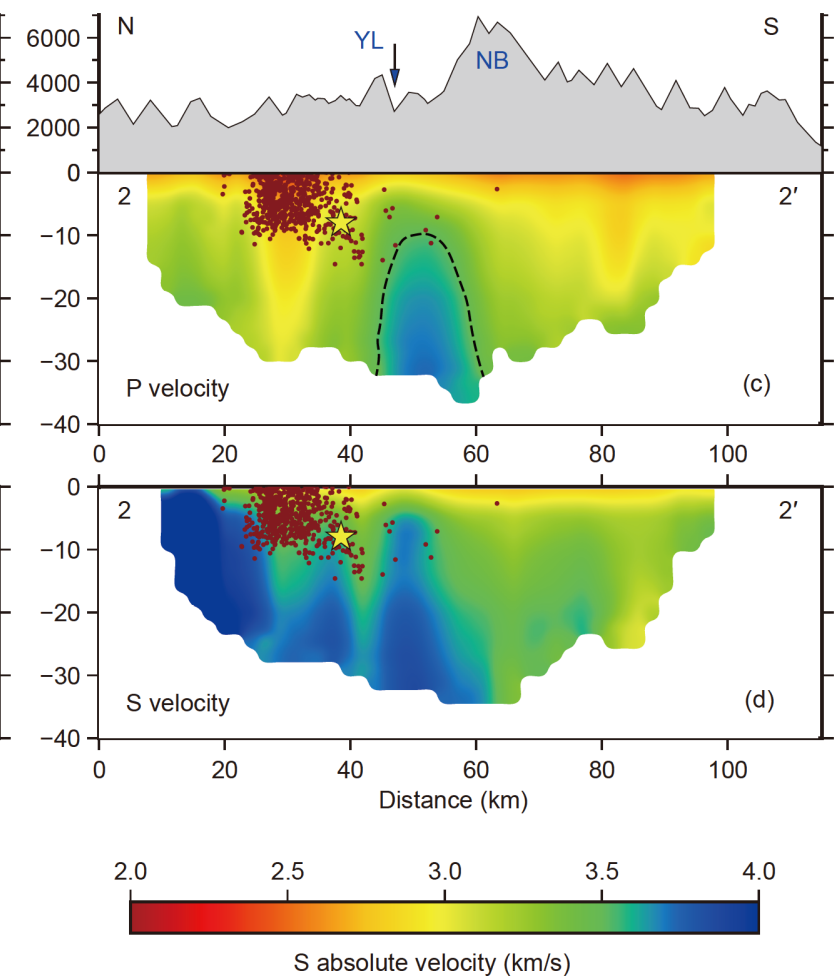

图 4 沿剖面1-1'和2-2'的P、S波速度结构. YL和蓝色剪头指示雅鲁藏布江流经位置; NB指示南迦巴瓦峰投影到剖面上的位置; 黄色五角星 代表主震位置, 红色圆点表示距离剖面 $5 \mathrm{~km}$ 范围内的余震在剖面上的投影. (a), (b) 分别指示剖面1-1'的P波和S波速度结构; (c), (d) 分别指示剖 面2-2'的P波和S波速度结构; (a), (c) 黑色虚线表示图3中紧邻南迦巴瓦峰西北侧的P波速度高异常区

Figure 4 P, S wave velocity structure along profile $1-1^{\prime}$ and $2-2^{\prime}$. The blue shears and YL indicate the position of the Yarlung Zangbo River; NB indicates the position of the Namche Barwa Peak projected onto the profile; the yellow star represents the epicenter position of Mainling earthquake; the red dots represent the aftershocks in the range of $5 \mathrm{~km}$ from the profile. (a) and (b) indicate the P-wave and S-wave velocity structures along the profile $1-1^{\prime}$, respectively, (c) and (d) indicate the P-wave and S-wave velocity structures along the profile $2-2$, respectively. The black dotted lines in (a) and (c) indicate the high P-wave velocity anomaly area on the northwest side of the Namche Barwa Peak

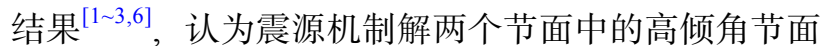
走向与余震分布走向、XXL断裂走向具有较好的一致 性(图1). 推测该节面是主震的发震断层面, 同时该节面 与F1、F2和F3的断层面都具有高倾角特征，即主震发 震断层面和余震集中分布的断层面产状比较一致，表 明米林地震主震和余震可能是发生在一组与XXL断裂 相平行的次级高角度逆冲、兼具右旋走滑为特征的活 动断裂带或其上下盘的破碎带内. 结合中国科学院青 藏高原研究所和中国地震局地质研究所研究人员对主 震事件的定位结果 ${ }^{[1,2]}$, 推测F2为主震发震断层. 需要指 出的是, 余震在平面上的分布形态并非严格的NW-SE 向直线分布，而具有略微“S”状弯曲形变特征，此形变 在西北端更为明显. 原因可能是南迦巴瓦构造结与拉 萨地体发生NE向强烈挤压，导致该组断裂发生弯曲变 形，属于喜马拉雅东构造结地区对印度板块持续向北
推挤下的形变调节方式.

在地壳浅层部位，地震体波速度更易受到断裂分 布、岩石破碎程度的影响. 沿着大型活动断层通常会

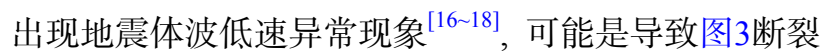
带F1和F2所处位置的P、S波以及图4(c)左侧浅层P波 速度偏低的原因之一，加之图4(a)，(b)右侧河流冰川地 貌发育, 可能导致该位置浅层P波和S波速度偏低. 南迦 巴瓦变质体作为印度板块NE向碰撞俯冲的前缘地带, 断裂发育集中, 破碎程度较高, 一定程度上导致该区域 地震波速度偏低. 另一方面, 岩体性质也可以影响地震 波速度，例如岩体裂隙发育、流体渗透、熔融态和特 殊矿物富集可引起地震体波低速异常 ${ }^{[19 ~ 21]}$ 。在南迦巴 瓦变质体西侧、北侧和东侧的拉萨地体主要由元古代 结晶基底变质杂岩和古生代变质砂板岩以及白严纪钲 碱性花岗岩组成 ${ }^{[15]}$, 岩性相对古老且刚冷, 可能是该区 
域P波、S波速度偏高的原因. 而南迦巴瓦变质体的复 式背形构造主要由经历高级变质和高温韧性变形作用 的高压麻粒岩、长英质片麻岩和黑云斜长角闪岩等岩 类组成 ${ }^{[15]}$ ，其石英矿物含量的增加导致体波速度降 低 ${ }^{[22]}$, 加之印度板块自 65 42 $\mathrm{Ma}^{[5]}$ 向欧亚大陆碰撞挤 压俯冲到拉萨地体下的过程中，原岩发生强烈混合岩 化与重熔融作用, 岩性相对年轻而软热, 导致过南迦巴 瓦峰走向东西的“界线”南侧区域相对北侧P波速度负 异常, S波速度相对北侧拉萨地体偏低(图3,4(d)).

除此之外，在紧邻南迦巴瓦峰西北侧P波波速高异 常区的主体岩类中，含有大量石榴石单斜辉石岩、石 榴石角闪岩、蓝晶石和含有石榴石的钻质片岩 ${ }^{[15]}$. 石 榴石波速明显高于角闪石、斜长石、云母和石英等矿 物, 具有高波速、低各向异性特点 ${ }^{[23-26]}$, 地震波在石榴 石富集区域速度偏高 ${ }^{[27]}$, 可能导致了该区域P波速度的 明显正异常. 大量石榴石辉石岩的出现, 是印度板块俯 冲到拉萨地体之下后又折返回来的标志 ${ }^{[28]}$. 同时, 该区 域P波、S波速比偏高，可能反映了该区域地体软热的 性质 ${ }^{[29,30]}$. 结合该区域发现的大量高压麻粒岩 ${ }^{[15,31]}$ 等 幔源壳源岩类，推测是俯冲板片断离(break-off) ${ }^{[32]}$ 后, 地幔岩石圈物质上涌侵人 ${ }^{[31]}$, 改变了地壳浅层部位岩 石矿物组分, 导致相应区域地震波速异常. 结合图4中P 波、S波速度结构剖面高速异常区特点，推测在 $35 \mathrm{~km}$ 深度内，该区域主要岩类可能普遍含有石榴石，P波波 速高异常物性特征可延续至中地壳.
$\mathrm{P}$ 波、S波波速比值高低过渡区更易发生中强型地 震 $^{[33]}$, 米林 $M \mathrm{~s} 6.9$ 级地震便发生在波速比值高低过渡带. 根据震源区西南侧波速比偏高可能反映的塑性物理性 质，推测是导致震源区西南部位包括F3附近地震偏少 的原因之一. 在余震集中分布区域地震波P波速度负异 常反映了震中区地层破碎、活动断裂发育集中的构造 特点, 因此建议在南迦巴瓦变质体北端谨慎进行大型 工程设施建设.

\section{5 结论}

(1) 西兴拉断裂西南侧存在3条与西兴拉断裂走向 基本一致的次级高倾角活动断裂，该组断裂倾角自西 北端向东南端逐渐变陡，以强烈逆冲兼右行走滑为主 要特征, 在南迦巴瓦构造结持续NE向推挤作用下, 3 条 次级断裂发生了弯曲变形.

（2）北侧拉萨地体相对完整且岩性古老刚冷、南 侧及南迦巴瓦变质体相对破碎、断裂集中且岩石生成 年代较新岩性较热, 可能是导致南迦巴瓦峰以北区域 和以南区域体波速度差异的原因之一.

(3) 紧邻南迦巴瓦峰西北侧岩体含大量石榴石矿 物是可能引起该区域P波波速偏高的原因之一. 震中区 西南侧波速比偏大，以及剖面1-1'右侧 $\mathrm{P} 、 \mathrm{~S}$ 波和剖面 2-2'左侧 $\mathrm{P}$ 波波速偏低现象，可能与该区断裂集中地形 破碎, 加之河流冰川发育有关, 其中波速比偏大的区域 可能还与深部地幔岩石圈物质的上涌有关.

致谢＼cjkstart感谢中国科学院青藏高原研究所科研人员野外架设地震台站过程中的辛苦付出, 丁林院士在研究过程中提出的良好建 议, 两位审稿专家提出的宝贵意见. 文章所用图表由GMT软件绘制.

\section{参考文献}

1 Bai L, Li G H, Song B W. The source parameters of the M6.9 Mainling, Tibet earthquake and its tectonic implications (in Chinese). Chin J Geophys, 2017, 60: 4956-4963 [白玲, 李国辉, 宋博文. 2017年西藏米林6.9级地震震源参数及其构造意义. 地球物理学报, 2017, 60: 49564963]

2 Wei W, Xie C, Zhou B G, et al. Location of the mainshock and aftershock sequences of the M6.9 Mainling earthquake, Tibet (in Chinese). Chin Sci Bull, 2018, 63: 1493-1501 [韦伟, 谢超, 周本刚, 等. 西藏米林M6.9级地震及其余震序列地震定位. 科学通报, 2018, 63: 1493-1501]

3 Tang F T, You H C, Liang X H, et al. A discussion on seismoge fault of the Milin Ms6.9 earthquake, Tibet, and its tectonic attributes (in Chinese). Acta Geosci Sin, 2019, 40: 213-218 [唐方头, 尤惠川, 梁小华, 等. 西藏米林6.9级地震发震断层判定及其构造属性讨论. 地球学报, 2019, 40: 213-218]

4 Ding L, Zhong D, Yin A, et al. Cenozoic structural and metamorphic evolution of the eastern Himalayan syntaxis (Namche Barwa). Earth Planet Sci Lett, 2001, 192: 423-438

5 Deng Q D, Ran Y K, Yang X P, et al. Map of Active Tectonic in China (in Chinese). Beijing: Seismological Press, 2007 [邓起东, 再勇康, 杨晓平, 等. 中国活动构造图 (1: 400万). 北京: 地震出版社, 2007]

6 Liu Y H, Shan X J, Zhang Y F, et al. Use of seismic waveforms and InSAR data for determination of the seismotectonics of the mainling Ms6.9 earthquake on Nov. 18, 2017 (in Chinese). Seismol Geol, 2018, 40: 1254-1275 [刘云华, 单新建, 张迎峰, 等. 基于地震波及InSAR数据的2017年 
11月18日西藏米林Ms6.9地震发震构造. 地震地质, 2018, 40: 1254-1275]

7 Bai L, Li G, Khan N G, et al. Focal depths and mechanisms of shallow earthquakes in the Himalayan-Tibetan region. Gondwana Res, 2017, 41: 390-399

8 Yin F L, Han L B, Jiang C S, et al. Interaction between the 2017 M6.9 Mainling earthquake and the 1950 M8.6 Zayu earthquake and their impacts on surrounding major active faults (in Chinese). Chin J Geophys, 2018, 61: 3185-3197 [尹凤玲, 韩立波, 蒋长胜, 等. 2017年米林6.9级地震与 1950年察隅8.6级地震的关系及两次地震对周边活动断层的影响. 地球物理学报, 2018, 61: 3185-3197]

9 Schaff D P. Optimizing correlation techniques for improved earthquake location. Bull Seismol Soc Am, 2004, 94: 705-721

10 Koulakov I, Zabelina I, Amanatashvili I, et al. Nature of orogenesis and volcanism in the caucasus region based on results of regional tomography. Solid Earth, 2012, 3: 327-337

11 Koulakov I. Lotos code for local earthquake tomographic inversion: Benchmarks for testing tomographic algorithms. Bull Seismol Soc Am, 2009, 99: 194-214

12 Tong P. Seismic tomography methods and their application (in Chinese). Doctor Dissertation. Beijing: Tsinghua University, 2012 [童平. 地震层析 成像方法及其应用研究. 博士学位论文. 北京: 清华大学, 2012]

13 Tapponnier P, Xu Z Q, Roger F, et al. Oblique stepwise rise and growth of the Tibet Plateau. Science, 2001, 294: 1671-1677

14 Ding L, Zhong D L. The tectonic evolution of the eastern Himalaya syntaxis since the collision of the Indian and Eurasian plates (in Chinese). Chin J Geol, 2013, 48: 317-333 [丁林, 钟大麥. 印度与欧亚板块碰撞以来东喜马拉雅构造结的演化. 地质科学, 2013, 48: 317-333]

$15 \mathrm{Xu}$ Z Q, Cai Z H, Zhang Z M, et al. Tectonics and fabric kinematics of the Namche Barwa terrane, Eastern Himalayan Syntaxis (in Chinese). Acta Petrol Sin, 2008, 24: 1463-1476 [许志琴, 蔡志慧, 张泽明, 等. 喜马拉雅东构造结一一南迦巴瓦构造及组构运动学. 岩石学报, 2008, 24: 14631476]

16 Mooney W D, Ginzburg A. Seismic measurements of the internal properties of fault zones. Pure Appl Geophys, 1986, 124: 141-157

17 Thurber C, Roecker S, Ellsworth W, et al. Two-dimensional seismic image of the San Andreas Fault in the Northern Gabilan Range, central California: Evidence for fluids in the fault zone. Geophys Res Lett, 1997, 24: 1591-1594

18 Fischer K M, Ford H A, Abt D L, et al. The lithosphere-asthenosphere boundary. Annu Rev Earth Planet Sci, 2010, 38: 551-575

19 Zhao D P, Kanamori H, Negishi H, et al. Tomography of the source area of the 1995 Kobe earthquake: Evidence for fluids at the hypocenter? Science, 1996, 274: 1891-1894

20 Takei Y. Effect of pore geometry on $V \mathrm{p} / V_{\mathrm{s}}$ : From equilibrium geometry to crack. J Geophys Res, 2002, 107: ECV 6-1-ECV 6-12

21 Sodoudi F, Yuan X, Asch G, et al. High-resolution image of the geometry and thickness of the subducting Nazca lithosphere beneath northern Chile. J Geophys Res, 2011, 116: B04302

22 Carmichael R S. Practical Handbook of Physical Properties of Rocks and Minerals. Florid: CRC Press, 2017

23 Kern H, Jin Z, Gao S, et al. Physical properties of ultrahigh-pressure metamorphic rocks from the Sulu terrain, eastern central China: Implications for the seismic structure at the Donghai (CCSD) drilling site. Tectonophysics, 2002, 354: 315-330

24 Gao S, Kern H, Jin Z M, et al. Poisson's ratio of eclogite: The role of retrogression. Earth Planet Sci Lett, 2001, 192: 523-531

25 Ji S, Saruwatari K, Mainprice D, et al. Microstructures, petrofabrics and seismic properties of ultra high-pressure eclogites from Sulu region, China: Implications for rheology of subducted continental crust and origin of mantle reflections. Tectonophysics, 2003, 370: 49-76

26 Chen Y, Jin Z M, Ou X G, et al. Deformation features of gneiss and UHP eclogite from ductile shear zone and its relation with seismic velocity anisotropy: Evidences from core samples at depth of 680-1200 m of CCSD (in Chinese). Acta Petrol Sin, 2004, 20: 97-108 [陈意, 金振民, 欧新 功, 等. 韧性剪切带中片麻岩和超高压榴辉岩变形特征及其与地震波速各向异性的关系: 来自中国大陆科学钻探(CCSD)680 1200米岩心的 证据. 岩石学报, 2004, 20: 97-108]

27 Wang Q, Ji S C, Xu Z Q, et al. Seismic properties of eclogites: Implications on crustal composition and exhumation mechanism of the Sulu ultrahigh-pressure metamorphic belt (in Chinese). Acta Petrol Sin, 2005, 21: 451-464 [王勤, 嵇少丞, 许志琴, 等. 榴辉岩的地震波性质: 对苏鲁 超高压变质带地壳成分和折返机制的探讨. 岩石学报, 2005, 21: 451-464]

28 Zhang Z M, Zheng L L, Wang J L, et al. Garnet pyroxenite in the Namjagbarwa Group - Complex in the eastern Himalayan tectonic syntaxis, Tibet, China: Evidence for subduction of the Indian continent beneath the Eurasian plate at 80-100 km depth (in Chinese). Chin Geol Bull, 2007, 26: 1-12 [张泽明, 郑来林, 王金丽, 等. 东喜马拉雅构造结南迦巴瓦岩群中的石榴辉石岩一一印度大陆向欧亚板块之下俯冲至80 100 km深 度的证据. 地质通报, 2007, 26: 1-12]

29 Wang C Y, Lou H, Lü Z Y, et al. S-wave crustal and upper mantle's velocity structure in the eastern Tibetan Plateau-Deep environment of lower crustal flow. Sci China Ser D-Earth Sci, 2008, 51: 263-274 [王椿镛, 楼海, 吕智勇, 等. 青藏高原东部地壳上地幔S波速度结构一一下地壳流的 深部环境. 中国科学D辑: 地球科学, 2008, 38: 22-32]

30 Liu Q L, Wang C Y, Yao Z X, et al. Study on crustal thickness and velocity ratio in mid-western North China Craton (in Chinese). Chin J Geophys, 2011, 54: 2213-2224 [刘琼林, 王椿镛, 姚志祥, 等. 华北克拉通中西部地区地壳厚度与波速比研究. 地球物理学报, 2011, 54: 2213-2224]

31 Ding L, Zhong D L. The characteristics of high pressure granulite facies metamorphism and its tectonic geological significance in the south of Tibet 
(in Chinese). Sci China Ser D-Earth Sci, 1999, 29: 385-397 [丁林, 钟大㐘. 西藏南迦巴瓦峰地区高压麻粒岩相变质作用特征及其构造地质意 义. 中国科学D辑: 地球科学, 1999, 29: 385-397]

32 Zhong D L, Ding L. Dynamic mechanism of the uplift of the Tibetan Plateau (in Chinese). Sci China Ser D-Earth Sci, 1996, 26: 289-295 [钟大责, 丁林. 青藏高原的隆起过程及其机制探讨. 中国科学D辑: 地球科学, 1996, 26: 289-295]

33 Zhang H Y, Zhang G W, Wang X S, et al. Regional characteristics of wave velocity ratio in Jilin area and their tectonic implications (in Chinese). Seismol Geol, 2015, 37: 829-839 [张洪艳, 张广伟, 王晓山, 等. 吉林地区波速比分布特征及构造意义. 地震地质, 2015, 37: 829-839]

\section{补充材料}

图S1 余震在水平面和沿1-1'剖面的分布

图S2 沿各个剖面不同时间段内余震分布状况

图S3 检测板网格 $7 \mathrm{~km} \times 7 \mathrm{~km} \times 4 \mathrm{~km}$ 尺度时不同深度地震体波速度和波速比扰动情况

本文以上补充材料见网络版csb.scichina.com. 补充材料为作者提供的原始数据, 作者对其学术质量和内容负责. 


\title{
Aftershocks localization and shallow crustal velocity structure following the Ms6.9 Mainling earthquake in Tibet, China
}

\author{
Jin $\mathrm{Ye}^{1,2}$, Junmeng Zhao ${ }^{1}$, Hongbing Liu ${ }^{1 *}$, Heng Zhang ${ }^{1}$, Qiang $\mathrm{Xu}^{1}$ \& Shuze Chen ${ }^{1,2}$ \\ ${ }^{1}$ Laboratory of Continental Collision and Plateau Uplift, Institute of Tibetan Plateau Research, Chinese Academy of Sciences, Beijing 100101, China, \\ ${ }^{2}$ University of Chinese Academy of Sciences, Beijng 100049, China \\ * Corresponding author, E-mail: hbliu@itpcas.ac.cn
}

At 06:34 CST on November 18, 2017, an Ms6.9 earthquake struck Mainling prefecture, Nyingchi City, Tibet. The earthquake occurred at the frontier zone of collision and subduction in the eastern Himalayan syntaxis, a region of persistently strong compression between India and Eurasia. To monitor aftershock activity, the Institute of Tibetan Plateau Research, Chinese Academy of Sciences, installed 28 broadband seismic stations around the epicentral area and obtained 180 days of seismic observation data. The average spacing between stations was approximately $5 \mathrm{~km}$, which yielded good coverage of the source area and enriched the seismic data for the Eastern Himalayan syntaxis. In this paper, the hypodense events are refined by the hypoDD double-difference seismic location method and the local tomography software (LOTOS12), an algorithm for seismic location and velocity structure imaging joint inversion. The hypoDD seismic localization method uses waveform cross-correlation technology to achieve positioning using the minimum residuals of the actual and theoretical travel times of two earthquakes. It is widely used for close-range earthquakes and is suitable for regional earthquake research; the LOTOS algorithm is more appropriate for velocity structure inversion in regions with significant differences in physical properties. The results show that the aftershock zone is approximately $50 \mathrm{~km}$ long and $30 \mathrm{~km}$ wide and trends NW-SE. According to the aftershock distribution, three active faults are basically consistent with the strike of the Xixingla fault zone. These active fractures are similar in shape and have a NE dip direction, and the dip angles of the active faults gradually become steeper from NW to SE. Under the continuous NE thrusting action of the Namche Barwa syntaxis, the three secondary fractures have undergone bending deformation. This deformation is associated with the adjustment mode of the eastern Himalayan syntaxis where the Indian plate continues to push Eurasia northward. At the same time, combining these results with those of the LOTOS-12 algorithm, the distribution of the Pg wave and Sg wave velocity disturbance in the shallow crust $(20 \mathrm{~km})$ and the wave speed ratio $(V \mathrm{p} / V \mathrm{~s})$ are obtained. The main shock was located in an abnormal transition zone of body wave velocity, and the aftershocks mostly occurred in the negative anomaly zone for $\mathrm{P}$ wave and $\mathrm{S}$ wave velocities, which reflects the characteristics of stratigraphic fractures and faults in the area with concentrated earthquakes. We suggest that this area should be avoided in the future when construction of engineering facilities is required north of Namche Barwa Peak. Overall, with Namche Barwa Peak as the boundary, the P wave and the $\mathrm{S}$ wave are generally characterized by high-speed anomalies in the north and low-speed anomalies in the south. This phenomenon may be related to the geological structure and petrophysical properties in this area, as the lithologies of the Lhasa terrane are old and cold; meanwhile, the metamorphic body in the south and the Namche Barwa syntaxis are relatively broken, the ages of rock formation are relatively young, and the lithologies are relatively hot and soft. In addition, high-speed P wave anomalies in the northwestern part of Namche Barwa Peak may be related to enrichment in garnet minerals in this area. The higher wave velocity ratio on the southwest side of the epicentral area, the lower P wave velocity on the right side of profile $1-1^{\prime}$ and the $\mathrm{P}$ wave on the left side of profile $2-2^{\prime}$ may be related to the fragmentation of the terrain in this area and the development of valley glaciers. The area where the wave velocity ratio is relatively large may also be related to the upwelling of asthenospheric and lithospheric material in the deep mantle.

Mainling earthquake, eastern Himalayan syntaxis, earthquake location, seismogenic structure, velocity structure doi: 10.1360/TB-2019-0545 